\title{
Role of Therapeutic Plasma Exchange in Resolution of Hyperhemolysis in a Patient Living with HIV/AIDS (PLHA) Diagnosed with Paroxysmal Cold Haemoglobinuria: A Case Report"
}

\author{
Anubhav Gupta ${ }^{1} \cdot$ Kiran Chaudhary $^{1} \cdot$ Ajay Bhatta $^{2} \cdot$ Bishakha Swain $^{2} \cdot$ \\ Hari Prasad ${ }^{2} \cdot$ Brinda Kakkar $^{3} \cdot$ Swati Asati $^{4}$
}

Received: 1 September 2020/ Accepted: 13 November 2020/Published online: 22 November 2020

(C) Indian Society of Hematology and Blood Transfusion 2020

\begin{abstract}
Paroxysmal cold haemoglobinuria ( $\mathrm{PCH})$ is an acquired cause of haemolytic anaemia. It is caused by the biphasic IgG antibodies that sensitize and attach the red cells at lower temperature; detach and rebind on rewarming. Donath-Landsteiner antibody test is the diagnostic test for PCH. Management of PCH mainly includes supportive care but sometimes disease becomes severe and lifethreatening. We describe a similar severe and life-threatening case of $\mathrm{PCH}$ who was managed by plasma exchange followed by packed red cell transfusion.
\end{abstract}

Keywords Paroxysmal cold haemoglobinuria · Plasma exchange $\cdot$ Donath-landsteiner (DL) antibody

$\begin{array}{ll}\text { Abbreviations } & \\ \text { PRBC } & \text { Packed red blood cell } \\ \text { DAT } & \text { Direct antiglobulin test } \\ \text { LDH } & \text { Lactate dehydrogenase } \\ \text { PLHA } & \text { People living with HIV/AIDS } \\ \text { TPE } & \text { Therapeutic plasma exchange } \\ \text { DL antibody } & \text { Donath-landsteiner antibody }\end{array}$

Anubhav Gupta

dr.anubhavgupta@yahoo.com

1 Department of Transfusion Medicine, Atal Bihari Vajpayee Institute of Medical Sciences and Dr Ram Manohar Lohia Hospital Delhi, New Delhi 110001, India

2 Department of Medicine, Atal Bihari Vajpayee Institute of Medical Sciences and Dr Ram Manohar Lohia Hospital Delhi, New Delhi, India

3 Department of Transfusion Medicine, Institute of Liver and Biliary Sciences, New Delhi, India

4 Department of Obstetrics \& Gynaecology, Atal Bihari Vajpayee Institute of Medical Sciences and Dr Ram Manohar Lohia Hospital Delhi, New Delhi, India

$\begin{array}{ll}\text { AIHA } & \text { Autoimmune haemolytic anaemia } \\ \text { ART } & \text { Anti retroviral therapy } \\ \text { PNH } & \text { Paroxysmal nocturnal haemoglobinuria } \\ \text { PCH } & \text { Paroxysmal cold haemoglobinuria } \\ \text { ASFA } & \text { American society of apheresis } \\ \text { TM } & \text { Transfusion medicine } \\ \text { IAT } & \text { Indirect antiglobulin test } \\ \text { ACD-A } & \text { Acid citrate dextrose-A } \\ \text { HIV } & \text { Human immunodeficiency disease }\end{array}$

\section{Introduction}

Paroxysmal cold haemoglobinuria $(\mathrm{PCH})$ is a rare type of autoimmune haemolytic anemia (AIHA) seen due to $\operatorname{IgG}$ biphasic hemolysin which is capable of binding the red cells at lower temperature resulting in complement mediated intravascular haemolysis at body temperature. The hemolysin involved was first described by Donath-Landsteiner in 1904 and is known as donath-landsteiner (DL) antibody. It is described as an abrupt onset of severe anaemia and hemoglobinuria.[1]

Historically, PCH was commonly encountered in patients with secondary or tertiary syphilis, which is rarely seen now. [1,2] It presents commonly as an acute transient condition that is secondary to a viral infection (mumps, measles, chicken pox, Epstein-Barr virus, cytomegalovirus, influenza, parvovirus B19, coxsackie virus and adenovirus) particularly in young children. However, it may also be associated with immunologic disorders such as diffuse large B-cell lymphoma and chronic lymphocytic leukemia. At times the cause may remain unknown i.e. a specific pathogen is not identified in these patients. [3-7] 
Pathophysiologically, the disease represents molecular mimicry and cross reactivity of the antibodies stimulated by the viruses with the normal red cells, resulting in alteration of $\mathrm{T}$ suppressor cell function leading to autoantibody formation [1]. The DL antibody (autoantibody) has shown specificity for the $P$ antigen which is expressed on red cells and microorganism cell wall. Donath-landsteiner (DL) test is considered as the gold standard test for diagnosing patients presenting with PCH. [2] There are handful of case reports demonstrating the role of plasma exchange in PCH. Burman AR et al. [8] in 2002 tried first plasma exchange on paediatric patient and observed clinical improvement. Here, we report a case highlighting the role of therapeutic plasma exchange (TPE) in resolving hyperhaemolysis in a 35-year-old female patient living with HIV/AIDS (PLHA) diagnosed with PCH.

\section{Case Report}

A 35 year old female presented with complaints of palpitations, generalized weakness, shortness of breath and dizziness of one month duration which was associated with dark colour stools and urine since three days. She was admitted to our hospital with above mentioned complaints for further management. Patient was a known case of HIV/ AIDS (diagnosed in 2006) in clinical stage 3 on antiretroviral therapy (ART: zidovudine, lamivudine and nevirapine). Past history also revealed that patient was a chronic alcoholic and has also been diagnosed with chronic pancreatitis. On examination, patient had severe pallor, sinus tachycardia with pulse rate of 112 beats per minute, breathlessness with $\mathrm{SpO}_{2}$ of $94 \%$ on room air and blood pressure of 100/60 mm Hg. She received supportive care along with fluid resuscitation, intravenous (I.V.) iron, vitamin $\mathrm{B}_{12}$, folic acid, pantoprazole, and ceftriaxone. At the time of admission, her baseline haemoglobin was $3.7 \mathrm{~g} /$ $\mathrm{dL}$ for which she also transfused with two unit of packed red blood cells (PRBCs). Table 1 summarises her base line laboratory parameters.

Next day, clinicians noticed that patient was passing dark coloured urine. Laboratory investigations revealed further fall in haemoglobin, raised total bilirubin, increased lactate dehydrogenase (LDH) levels, undetectable haptoglobin levels and haemoglobinuria. Peripheral smear revealed anisopoikilocytosis, spherocytes and polychromasia which were suggestive of haemolytic anemia and bone marrow aspirate showed normoblast with megaloblast with myeloid series in various stages of maturation and normal megakaryocytes. Her ART was changed to abacavir, lamivudine and efavirenz to rule out drug induced haemolysis. Samples were sent for transfusion reaction workup as per the transfusion medicine (TM) departmental policy.

In view of intravascular haemolysis with haemoglobinuria, the initial differential diagnoses [9] for this patient included (1) mismatched blood transfusion: which was ruled out with repeat blood grouping and cross match confirmation, (2) septicaemia: which was ruled out as patient's blood cultures were negative, (3) microangiopathic anaemia, march haemoglobinuria, favism: which were ruled out after taking detailed history with absence of symptoms, (4) paroxysmal nocturnal haemoglobinuria (PNH): flowcytometry was normal for CD-55 and CD-59, (5) G6PD deficiency: which was ruled out as G6PD levels were within normal limits and (6) paroxysmal cold haemoglobinuria $(\mathrm{PCH})$ : patient's mono-specific direct antiglobulin test (DAT) was negative for $\operatorname{IgG}$ and $1+$ positive for C3d. Direct and indirect DL test was positive, though the $\mathrm{P}$ specificity of antibody could not be confirmed. ELISA was positive for parvovirus B19 IgG antibodies but polymerase chain reaction (PCR) was negative for parvovirus DNA.

In view of non-responding anaemia and risk of flare up of opportunistic infections in HIV/AIDS with immunosuppressive therapy, the case was discussed with TM specialist and therapeutic plasma exchange (TPE) followed by PRBC transfusion was planned. A total of three procedures of TPE were performed using central venous access with $4 \%$ albumin as primary replacement fluid and ACD-A as anticoagulant. An average of one plasma volume was removed per procedure. TPE procedure 1 was initiated at patient hemoglobin $(\mathrm{Hb})$ of $3.2 \mathrm{~g} / \mathrm{dl}$ and haematocrit of $10 \%$. Total $3731 \mathrm{ml}$ of whole blood was processed and $2511 \mathrm{ml}$ of the plasma was removed (one plasma volume) and replaced with $2458 \mathrm{ml}$ of $4 \%$ albumin, normal saline followed by two-unit PRBC transfusion. Removed plasma was dark brown as shown in Fig. 1. Hemoglobin content of the removed plasma bag was calculated as $5 \mathrm{~g}(0.2 \mathrm{~g} / \mathrm{dl})$. On next day patient $\mathrm{Hb}$ was raised to $8 \mathrm{~g} / \mathrm{dl}$ but patient persistently complained of dark colour urine though she was symptomatically better with improvement in palpitation, breathlessness and increase in appetite. Monospecific DCT was negative after the procedure. $\mathrm{Hb}$ was maintained above $8 \mathrm{~g} / \mathrm{dl}$ for next three days but fell to $6 \mathrm{~g} / \mathrm{dl}$ on the fourth day. Second procedure of TPE was planned and about $3488 \mathrm{ml}$ of whole blood was processed and $1787 \mathrm{ml}$ of the plasma was removed and replaced with $1653 \mathrm{ml}$ of $4 \%$ albumin, normal saline followed by one-unit PRBC transfusion. $\mathrm{Hb}$ content of removed plasma bag was $1.2 \mathrm{~g}$ i.e. lesser than compared with procedure 1 . Patient improved symptomatically and did not complain any further haemoglobinuria following the second procedure of TPE. Before discharge, third procedure of plasma exchange was done and removed 
Table 1 Base line laboratory parameters

\begin{tabular}{|c|c|}
\hline Parameters & Base line values \\
\hline $\begin{array}{l}\mathrm{Hb}(\mathrm{g} / \mathrm{dl}) \\
\mathrm{M}=13-17.5 \mathrm{~g} / \mathrm{dl} \\
\mathrm{F}=11-16.5 \mathrm{~g} / \mathrm{dl}\end{array}$ & $3.7 / \mathrm{dl}$ \\
\hline $\begin{array}{l}\text { TLC (cumm) } \\
(4000-11,000 / \text { cumm })\end{array}$ & 12,800 cumm \\
\hline DLC (cell\%) & $\begin{array}{l}N=78 \\
L=20 \\
E=01 \\
B=00 \\
M=01\end{array}$ \\
\hline $\begin{array}{l}\text { Platelet (cumm) } \\
(1.5-4.5 \text { lakhs/cumm) }\end{array}$ & 1.68 lakhs/cumm \\
\hline $\begin{array}{l}\mathrm{PCV}(\%) \\
\mathrm{M}=40-50 \% \\
\mathrm{~F}=33-44 \%\end{array}$ & $10.8 \%$ \\
\hline $\begin{array}{l}\text { Total RBC (million cells } / \mu \mathrm{L} \text { ) } \\
\mathrm{M}=4.7-6.1 \text { million cells } / \mu \mathrm{L} \\
\mathrm{F}=4.2-5.4 \text { million cells } / \mu \mathrm{L}\end{array}$ & $1.28($ million cells $/ \mu \mathrm{L})$ \\
\hline $\begin{array}{l}\operatorname{MCV}(f l) \\
(80-94 \mathrm{fl})\end{array}$ & $68 \mathrm{fl}$ \\
\hline $\begin{array}{l}\mathrm{MCH}(\mathrm{pg}) \\
(27-33 \mathrm{pg})\end{array}$ & $24 \mathrm{pg}$ \\
\hline $\begin{array}{l}\mathrm{MCHC}(\mathrm{g} / \mathrm{dl}) \\
(32-36 \mathrm{~g} / \mathrm{dl})\end{array}$ & $30 \mathrm{~g} / \mathrm{dl}$ \\
\hline $\begin{array}{l}\text { Reticulocyte count }(\%) \\
(0.5-2 \%)\end{array}$ & $0.5 \%$ \\
\hline Peripheral blood smear & Anisopoikilocytosis, spherocytes and polychromasia \\
\hline Bone marrow aspirate & $\begin{array}{l}\text { Normoblast with megaloblast with myeloid series in various } \\
\text { stages of maturation and normal megakaryocytes }\end{array}$ \\
\hline PNH (Flocytometry) & Normal CD 55 and CD 59 \\
\hline G6PD & Normal \\
\hline Direct antiglobulin test (DAT) & AHG-1 + (IgG-Negative, C3d- 1 +) \\
\hline Indirect antiglobulin test (IAT) & Negative \\
\hline Donath-Landsteiner test & Positive \\
\hline $\begin{array}{l}\text { Urea }(\mathrm{mg} / \mathrm{dl}) \\
(20-40 \mathrm{mg} / \mathrm{dl})\end{array}$ & $30 \mathrm{~g} / \mathrm{dl}$ \\
\hline $\begin{array}{l}\text { Creatinine }(\mathrm{mg} / \mathrm{dl}) \\
(0.3-1.1 \mathrm{mg} / \mathrm{dl})\end{array}$ & $1.2 \mathrm{mg} / \mathrm{dl}$ \\
\hline $\begin{array}{l}\text { Uric acid }(\mathrm{mg} / \mathrm{dl}) \\
(2-6 \mathrm{mg} / \mathrm{dl})\end{array}$ & $5.8 \mathrm{mg} / \mathrm{dl}$ \\
\hline $\begin{array}{l}\text { Total bilirubin }(\mathrm{mg} / \mathrm{dl}) \\
(0.1-1 \mathrm{mg} / \mathrm{dl})\end{array}$ & $7.2 \mathrm{mg} / \mathrm{dl}$ \\
\hline Direct bilirubin (mg/dl) & $1.6 \mathrm{mg} / \mathrm{dl}$ \\
\hline Indirect bilirubin (mg/dl) & $5.6 \mathrm{mg} / \mathrm{dl}$ \\
\hline $\begin{array}{l}\operatorname{AST}(\mathrm{u} / \mathrm{l}) \\
(15-33 \mathrm{u} / \mathrm{l}))\end{array}$ & $55 \mathrm{u} / 1$ \\
\hline
\end{tabular}


Table 1 continued

\begin{tabular}{lc}
\hline Parameters & Base line values \\
\hline ALT $(\mathrm{u} / \mathrm{l})$ & $60 \mathrm{u} / \mathrm{l}$ \\
$(20-40 \mathrm{u} / \mathrm{l})$ & $253 \mathrm{u} / \mathrm{l}$ \\
ALP $(\mathrm{u} / \mathrm{l})$ & $136 \mathrm{meq} / \mathrm{l}$ \\
$(44-147 \mathrm{u} / \mathrm{l})$ & \\
$\mathrm{Na}+(\mathrm{meq} / \mathrm{l})$ & $3.8 \mathrm{meq} / \mathrm{l}$ \\
$(135-145 \mathrm{meq} / \mathrm{l})$ & \\
$\mathrm{K}+(\mathrm{meq} / \mathrm{l})$ & $103 \mathrm{meq} / \mathrm{l}$ \\
$(3.5-4.5 \mathrm{meq} / \mathrm{l})$ & \\
$\mathrm{Cl}-(\mathrm{meq} / \mathrm{l})$ & $4.8 \mathrm{~g} / \mathrm{dl}$ \\
$(96-106 \mathrm{meq} / \mathrm{l})$ & \\
Total protein $(\mathrm{g} / \mathrm{dl})$ & $2.3 \mathrm{~g} / \mathrm{dl}$ \\
$(6-8 \mathrm{~g} / \mathrm{dl})$ & \\
Albumin $(\mathrm{g} / \mathrm{dl})$ & $1300 \mathrm{u} / \mathrm{l}$ \\
$(3.4-5.4 \mathrm{~g} / \mathrm{dl})$ & \\
$\mathrm{LDH}(\mathrm{u} / \mathrm{l})$ & 7.43 \\
$(140-250 \mathrm{u} / \mathrm{l})$ & $0.9 \mathrm{mmol} / \mathrm{l}$ \\
$\mathrm{pH}(7.35-7.45)$ & \\
$\mathrm{iCa}+(\mathrm{mmol} / \mathrm{l})$ & \\
$(1.3-1.5 \mathrm{mmol} / \mathrm{l})$ &
\end{tabular}

plasma was clear straw-coloured. No complications noted during and after the procedure. Average plasma volume exchanged was around $2500 \mathrm{ml}$ and replaced with $2300 \mathrm{ml}$ with albumin and saline. Patient also received $10 \%$ calcium gluconate prophylactically during the procedure to rule out any citrate related toxicity. In view of low haemoglobin at the beginning of the procedure, cell separator was primed with PRBC. Mid-procedure patient's sample was drawn to check any signs of haemolysis. Table 2 summarises her plasma exchange procedural details.

At the time of discharge (day 15 of admission), patient was symptomatically better and hemodynamically stable. She was discharged on pantaprozole, folic acid, oral iron supplements and ART therapy. At two months follow up, patient was well and laboratory investigations showed haemoglobin level of $10.5 \mathrm{~g} / \mathrm{dL}$ and negative DAT.

\section{Discussion}

PCH was first described by Dressler in 1854 but DL test which is considered gold standard for $\mathrm{PCH}$ was first described by Donath Landsteiner in 1904. [10] Antibody identified in $\mathrm{PCH}$ is biphasic $\mathrm{IgG}$ which was responsible for paroxysms of severe anaemia and haemoglobinuria. [1] Red cells get sensitized at lower temperature where antibody binds and latter detaches and rebinds at body temperature activating the complement and causes intravascular red cell lysis. This antibody has been called "biphasic" due to different temperature of attachment and causing lysis of red cells. [6] In the past PCH was seen in patients of secondary and tertiary syphilis. Other causes include viral illnesses such as mumps, measles, chicken pox, Epstein-Barr virus, cytomegalovirus, influenza, parvovirus B19, coxsackie virus and adenovirus, and immunologic disorders such as diffuse large B-cell lymphoma and chronic lymphocytic leukemia. [3-7] In this present case we discuss the role of therapeutic plasma exchange (TPE) in resolving hyperhemolysis in a 35-yearold female patient living with HIV/AIDS (PLHA) diagnosed with $\mathrm{PCH}$.

Despite repeated compatible PRBC transfusions, haemoglobin of the patient was not raised and after every transfusion patient complaint of haemoglobinuria. Transfusion of warmed PRBC is not advocated as causative antibody does not react in compatibility testing at temperature greater than $4{ }^{\circ} \mathrm{C}$ [11]. This temperature dependent feature of $\mathrm{PCH}$ differentiates it from cold agglutinin disease (CAD) in which cold autoantibodies have a titre of $>1000$ and are reactive at $30{ }^{\circ} \mathrm{C}$. [11] American society for Apheresis (ASFA) mentions regarding role of plasma exchange in autoimmune hemolytic anemia- severe cold and warm type, however there is no specific mention regarding paroxysmal cold haemoglobinuria. Rational for plasma exchange in $\mathrm{PCH}$ was to remove low affinity DL antibody which are mostly intravascular. Because of transient and brief production of DL antibody and without significant rebound increase in production, plasma 

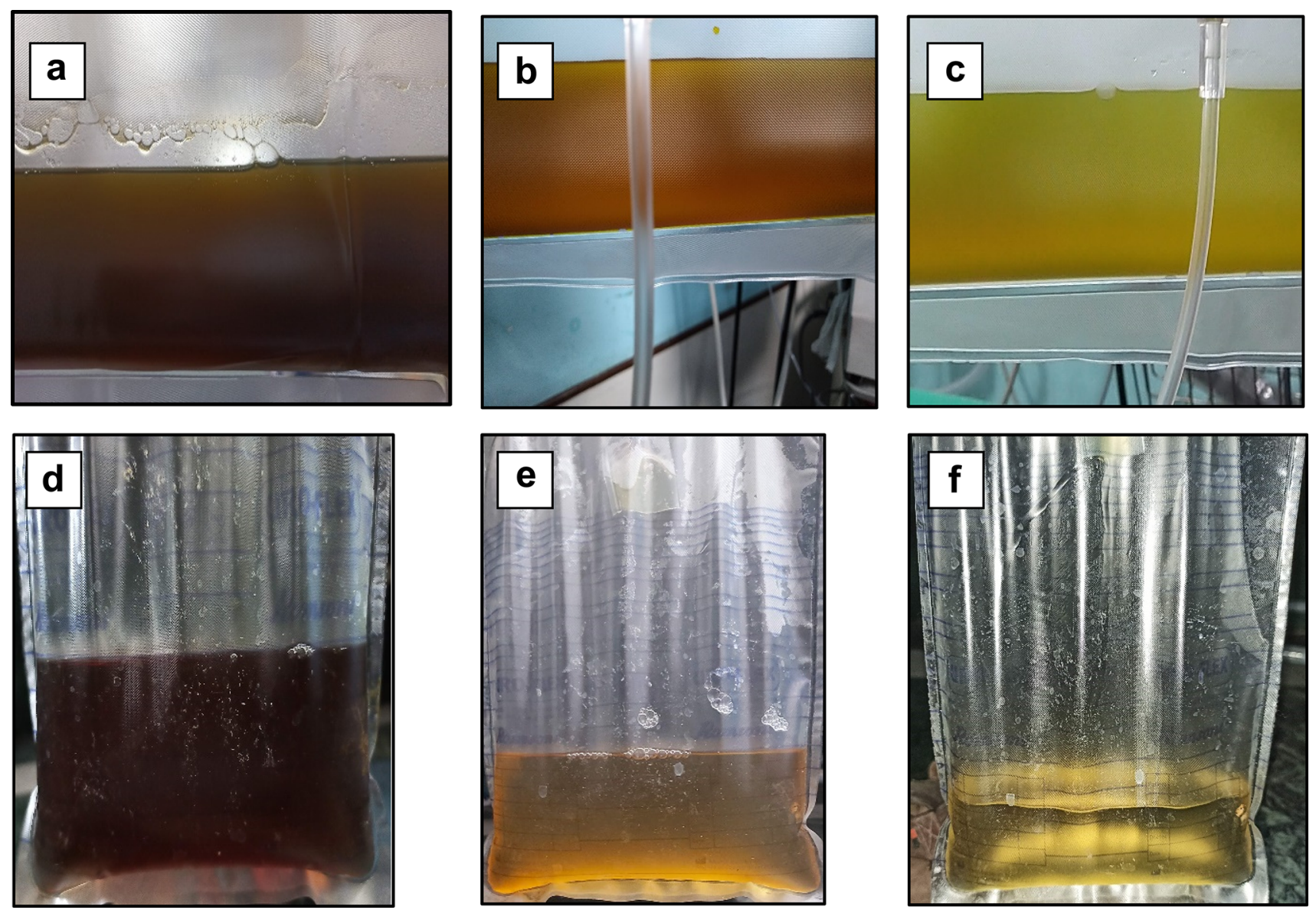

Fig. $1 \mathbf{a}, \mathbf{b}$ and $\mathbf{c}$ Colour of removed plasma bag during the 1st, 2nd and 3rd plasma exchange session. d, e and $\mathbf{f}$ Urine samples demonstrating improvement with respect to clearance of PFHb and reduction in bilirubin levels from 1st to the 3rd session of plasma exchange

Table 2 Details of plasma-exchange procedure

\begin{tabular}{lllll}
\hline Parameters & Procedure 1 & Procedure 2 & Procedure 3 & Plasma volume (PV) \\
\hline Total blood processed & $3731 \mathrm{ml}$ & $3488 \mathrm{ml}$ & $3434 \mathrm{ml}$ & 1 \\
Total plasma removed & $2511 \mathrm{ml}$ & $1787 \mathrm{ml}$ & $1754 \mathrm{ml}$ & 1 \\
Total plasma replaced & $2458 \mathrm{ml}$ & $1653 \mathrm{ml}$ & $1620 \mathrm{ml}$ & 1 \\
Hb in removed bag & $5 \mathrm{~g}$ & $1.2 \mathrm{~g}$ & Zero & NA \\
Replacement Fluid & Albumin + NS + PRBC & Albumin + NS + PRBC & Albumin + NS \\
\hline
\end{tabular}

Hb Haemoglobin; NA Not applicable; NS Normal Saline

exchange was tried to remove any formed DL antibodies. Similar case was reported by Burman AR et al. [8] in 2002 in which plasma exchange was first tried and authors observed similar improvement as we observed in our case. After first procedure of plasma exchange patient's general condition improved. Removed plasma was dark brown in colour with haemoglobin content of $5 \mathrm{~g}$. With the third procedure of plasma exchange, removed plasma was straw coloured. There was continuous improvement in general condition and laboratory parameters thereafter.

\section{Conclusion}

This is probably the first reported case on paroxysmal cold haemoglobinuria who underwent plasma exchange in HIV positive patient presenting with intravascular haemolysis. Patient had dramatic response after the procedure. Plasma exchange can be added as an effective adjuvant therapy in treating severe presentation of the disease especially in patients where immunosuppression is not advocated. 
Acknowledgements We are thankful to the patient for permitting us to use their case for presentation.

Authors Contribution All authors were involved in drafting, reviewing and revising the manuscript and gave intellectual inputs.

\section{Funding None.}

\section{Compliance with Ethical Standards}

Conflicts of interest Authors have no conflicts of interest to declare.

\section{References}

1. Eder AF (2005) Review: acute Donath-Landsteiner hemolytic anemia. Immunohematology 21(2):56-62

2. Petz LD (2008) Cold antibody autoimmune hemolytic anemias. Blood Rev 22(1):1-15

3. Bunch C, Schwartz FC, Bird GW (1972) Paroxysmal cold haemoglobinuria following measles immunization. Arch Dis Child 47(252):299-300

4. Göttsche B, Salama A, Mueller-Eckhardt C (1990) DonathLandsteiner autoimmune hemolytic anemia in children: A study of 22 cases. Vox Sang 58(4):281-286
5. Heddle NM (1989) Acute paroxysmal cold hemoglobinuria. Transfus Med Rev 3(3):219-229

6. O'Neill BJ, Marshall WC (1967) Paroxysmal cold haemoglobinuria and measles. Arch Dis Child 42(222):183-186

7. Sokol RJ, Booker DJ, Stamps R (1999) Erythropoiesis: paroxysmal cold haemoglobinuria: A clinico-pathological study of patients with a positive Donath-Landsteiner test. Hematology 4(2):137-164

8. Roy-Burman A, Glader BE (2002) Resolution of severe DonathLandsteiner autoimmune hemolytic anemia temporally associated with institution of plasmapheresis. Crit Care Med 30(4):931-934

9. Jameson JL (2018) Harrison's principles of internal medicine. McGraw-Hill Education, NewYork

10. Sokol RJ, Booker DJ, Stamps R (1998) Paroxysmal cold hemoglobinuria and the elusive Donath-Landsteiner antibody. Immunohematology 14:109-112

11. Simon TL, Mullough J, Snyder EL, Solheim BG, Strauss RG (eds) (2016) Rossi's principles of transfusion medicine. John Wiley, Chicheste

Publisher's Note Springer Nature remains neutral with regard to jurisdictional claims in published maps and institutional affiliations. 